easy stages and with the simplest mathematical methods to such an understanding of physical chemistry as will permit him to appreciate the more advanced treatises". This aim is fully achieved, and the new "Glasstone" will soon become well known to honours students in chem- istry. It should, however, appeal to a wider publie, for there are many chemists outside the universities who will welcome an opportunity of making themselves acquainted with the newer work and its relationship to the old.

S. SUGDeN.

\title{
DECREASE OF WILDFOWL THROUGHOUT THE WORLD
}

\section{International Wildfowl Inquiry}

Vol. 1: Factors affecting the General Status of Wild Geese and Wild Duck. Pp. $x+123$. (Cambridge : At the University Press, 1941.) 8s. 6d. net.

THE disquieting fact has to be faced that the steadily decreasing. To obtain accurate information on this decrease, and to seek some method of checking it, the International Committee for Bird Preservation recently carried out an exhaustive inquiry, the results of which are recorded in the volume under notice.

The destruction of bird life has so often in the past been allowed to continue until some rare species has been exterminated-witness the fate of the sea eagle, osprey and goshawk in Scotland - that it is good to know that some at least of European countries are alive to the potential danger in this decrease of their stock of geese and duck. Sweden, for example (p. 4), has afforded protection throughout the year for five years to all wildfowl in the large province of Jamtland. Contrast this with the state of affairs in Holland (p. 4) where it is estimated that a million wild duck are taken annually in decoys. It is satisfactory to know that few duck decoys are working in Britain. At one of these decoys-Orielton in Pembrokeshire - the duck are not killed, but after being caught and ringed are released. In the year 1935, 1,350 duck were caught and ringed here, and interesting light on their migrations has been shed. It is stated that in Eire and in Denmark duck decoys are illegal, but one wonders what the result of the present War will be as regards the praiseworthy efforts of European nations to conserve their stock of birds. Will Denmark continue such protection, and will Sweden continue to keep the great province of Jamtland a sanctuary? One fears that in the present bitter warfare, birds everywhere are bound to suffer.

This book contains interesting information on the destruction of the eggs of duck and geese in the High North. Captain J. H. MacNeile (p. 23) describes the raids made by Norwegian sealing sloops on the eggs of the eiderduck, which nest in large colonies in Spitsbergen. On the low islands off the Spitsbergen coast brent geese nest in the eider colonies, and the egg hunters make no distinction between the eggs of geese and eiders. Captain MacNeile mentions that in 1935, in early July, hundreds of eggs of eiders and brent geese were taken on one island group alone. The eggs were then hard set and, it might have been thought, useless as food. Captain MacNeile writes :

"How long can the brent geese survive such treatment? It seemed more than doubtful whether one single gosling could have been reared that year on any of the Liefde Bay islands, the principal stronghold of the species in northern Spitsbergen."

In Iceland the raven sucks great numbers of duck eggs. Major W. M. Congreve writes (p. 15) :

"Freme was responsible for shooting over fifty ravens on their morning and evening flights to Myvatn, from their distant mountain breeding homes. On the evening flight they were gorged with egg, and it was running from their beaks. Now one can say that this has always gone on. I suppose it has, but what has not gone on until, say, 50 years ago, is the invention of the breechloading gun, with the everlasting shooting by every Tom, Dick and Harry all over Europe and North Africa."

Chapter 3 of the book deals with another possible cause for the diminution of wildfowl in Britainthe undoubted decrease of the wigeon grass (Zostera) during the past fifteen years. This decrease was specially noticeable in the years 1931 and 1932.

Chapter 7 gives many interesting results of wildfowl ringing. The earliest ringing of duck was by H. C. C. Mortensen in Denmark, who published reports on the teal (in 1908) and on the pintail (1914). Since then, duck have been ringed in large numbers in Iceland, Holland, Germany, Sweden, Finland, and Russia. An unusually interesting ringing record is (p. 98) of a young wigeon ringed in Kinross, and recovered far to the north-west, in Iceland, during its first winter. 